\title{
Tax Deductions For Education Expenses
}

\author{
William A. Bottiglieri, Iona College, USA
}

Steven L. Kroleski, Iona College, USA

\begin{abstract}
Trade or business expenses are deductible if they are ordinary and necessary with respect to the trade or business in which they were incurred. Treasury Regulations bring education expenses into this purview but only if they maintain or improve skills already acquired or allow a taxpayer to maintain his current position. Expenses which qualify a taxpayer for a new trade or business or which enable one to meet the minimum standards of a trade or business are considered personal and thus not deductible. Where educational conferences are held out of town there are additional considerations which might limit the allowable deduction for related education expenses.
\end{abstract}

Keywords: tax deduction education; tax deduction travel; tax deduction teachers

\section{INTRODUCTION}

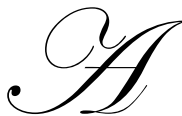

deduction for education expenses is permitted under Sec. 162 of the Internal Revenue Code of 1986, as amended (IRC). Under the proper circumstances such expenses are considered trade or business expenses which are allowable as deductions under Subsection A of IRC 162. Although this subsection only specifies the deductibility of salaries, expenses for travel and rental property used in a business, its applicability has been expanded by Treasury Regulation 1.162-5 which provides the authority and guidance for the deduction of education expenses.

For purposes of determining the deduction for trade or business expenses, including education expenses, one must be presently engaged in a trade or business, either as a separate business entity such as a corporation or as a sole proprietor. However, an employee is also considered to be engaged in a trade or business, i.e. the trade or business of performing the services he renders at his place of work. Accordingly, when we refer to teachers, they are considered to be engaged in the trade or business of teaching. This allows what is commonly referred to as employee business expenses to come within the ambit of IRC 62 and the related regulations and IRS positions (Rev. Rule 6097, 1960-1 CB 69). Further, in order for any of the trade or business deduction rules to apply a taxpayer must be currently engaged in his or her trade or business at the time the subject expenses are incurred. The language used in much of the literature is that these expenses are incurred "in connection with" a trade or business. Accordingly, a taxpayer who is not currently employed or not otherwise engaged in a trade or business is not entitled to a trade or business deduction, even for qualifying expenses (Rev. Rule 60-97, 1960-1 CB 69). Thus if a taxpayer who is presently not engaged in a trade or business and has not been for an extended period of one year or more undertakes education or training in anticipation of resuming his previous trade or business the cost of such education is not deductible. Periods of temporary inactivity such as caused by vacations, illness or temporary leaves of absence do not constitute the absence of a trade or business. For a teacher, he will not be considered to have ceased engaging in his employment while on sabbatical or over a summer break (Rev. Rule 60-97, 1960-1 CB 69).

In general, a deduction for education expenses is allowable if the education either (a) maintains or improves existing skills required by the individual in his employment or other trade or business or (b) meets the express requirements of the individual's employer to retain the individual's job status or rate of compensation. Education expenses incurred by an employee are not deductible if the expenses are required in order to meet the minimum requirements for qualification of his intended employment or if the expenses qualify him for a new trade or business. In these cases, the expenses will be treated as personal in nature because they have not been incurred in a trade or business but rather as a means of entering a new trade or business. Job-hunting expenses provide a clear example of this limitation. Such expenses incurred by an individual seeking his first job are not deductible for the simple reason that the individual is not in a trade or business yet and so cannot have incurred expenses in connection with a 
business he doesn't yet have. After the individual is employed these expenses would be deductible to find another position in the same field of work (Rev. Rul. 75-120, 1975-1, CB 55). In the case of education expenses, once an individual is engaged in a trade or business any education which allows him to either remain there or make vertical movements is deductible. However, education which allows him to gain entry into a new trade or business, by a lateral move or otherwise, is not deductible.

The broad support for the deduction of education expenses relating to a trade or business is contained in IRC Sec. 162. Such expenses are deductible as are other trade or business expenses which are deemed to be "ordinary and necessary expenses" in connection with a trade or business. The term "ordinary" refers to an expense which is customary or usual in a particular business (Welch v. Helvering, 12AFTR1456). The term "necessary" refers to an expense that is appropriate or helpful in the conduct of a business rather than essential (Blackmer v. Commr., 13AFTR957).

Treasury Regulation Sec. 1.162-5 provides the conceptual framework for deducting education expenses with examples of its application. This section allows a deduction for education expenses if they maintain or improve skills already acquired in a present position or if they enable the taxpayer to meet the express requirements of the individual's employer or applicable law as a condition to retaining the employment or position (Treas. Reg. 1.1625(a)). These provisions apply even though the education may lead to a degree. However, even if education expenses meet the above requirements they will be considered personal and therefore not deductible if they allow the taxpayer to meet the minimum educational requirements of a trade or business or they qualify the taxpayer for a new trade or business (Treas. Reg. 1.162-5(b)).The minimum educational requirement with respect to a position in an educational institution is the minimum level of education in terms of degree normally required at the time the individual is hired. An individual will ordinarily be considered to have met the requirements if, for example, if he has tenure or his present service is being counted towards tenure. Someone in a provisional or temporary position pending completion of an anticipated degree would not have met the minimum educational requirements and thus could not deduct any educational expenses.

The other category of educational expenses which are not deductible are those which qualify the taxpayer for a position in a new trade or business. Cases in this area indicate that there is a wide range of interpretation determining what exactly constitutes a new trade or business. Merely changing duties does not constitute a new position if the new duties involve the same general type of work as the individual was involved in before engaging in the education program. With respect to teaching, the regulations state that "all teaching and related duties shall be considered to involve the same type of general work" (Treas. Reg. 1.162-5(b)(3)(i)). Examples provided in this section of changes in duties which do not constitute a new trade or business are (i) classroom teacher in one subject to classroom teacher in another subject; (ii) classroom teacher to guidance counselor and (iii) classroom teacher to principal. Despite the premise in the relevant Treasury Regulation that all teaching is considered the same type of work there have been cases in which expenses of a teacher were not deductible. For example, an elementary school music teacher who left her job to get a PhD in music and then obtained a position as an Assistant Professor in the music department of the University could not deduct the expenses of getting the $\mathrm{PhD}$ (IRS letter Ruling 9316005). In addition, examples provided by the regulations in areas other than teaching indicate that (i) an employee or one self-employed practicing a profession who attends law school at night and obtains a law degree may not deduct the cost of attending law school because this course of study qualifies him for a new trade or business. This is so notwithstanding the taxpayer's intent to continue practicing his non-legal profession even after obtaining his law degree (Treas. Reg. 1.162-5(b)(3)(ii)).

Courts consider a taxpayer's ability to perform significantly different tasks and functions after obtaining the additional education in evaluating the allowance of deduction. Any specialized skills acquired in continuing education must be in the same general type of work albeit in an advanced position. The costs of legal education have been routinely denied as deductions in all cases in which the taxpayer had not already been awarded a legal degree. This is so regardless of whether the employer required the legal degree and even where the taxpayer did not use the legal degree in his position. In the tax court memorandum decision in Galligon (TC Memo 2002-150), taxpayer was a law library manager and obtained a law degree to enhance her skills which were required in her daily functions. She did not practice law and her employer did not require the degree. Nonetheless, the court denied the deduction because the degree did qualify her for a new position. 
The cost of obtaining an advanced degree such as an MBA is generally considered deductible if the taxpayer broadens his expertise within his present field rather than obtains qualifications to enter a new field. The present employment status of the taxpayer is a crucial factor in determining the deductibility of the MBA educational expenses. In the Tax Court memorandum decision in McEwen (TC Memo 2004-107), the taxpayer had been employed by two financial analyst firms after receiving her BBA degree. It was well known that these firms required an MBA for promotion. Had taxpayer continued her employment with either of these firms and sought and received an MBA in an effort to obtain a promotion the costs of the education would clearly had been deductible. However, the taxpayer resigned her position and completed her MBA program at a time when she was unemployed. After receiving her degree she obtained a position with a firm that required the MBA for employment. The court rightfully denied the deduction ruling that she had obtained education which qualified her for a new position which was different from the one previously held. Had the taxpayer returned to her previous employment after receiving her degree, even in an advanced position, the deduction would have been allowed.

In most cases MBA candidates are presently working and incur the education expenses at that time. The issue in determining deductibility is whether the education expenses qualify these individuals for a new position or simply improve their current skills. The regulations cite as examples of qualifying courses those which would be considered refresher courses or courses dealing with current developments in taxpayer's field (Treas. Reg. 1.1625(c)). Courts have held that education need only "enhance the taxpayer's existing skills" and have a direct relationship to the individual's responsibilities. In the case of an MBA degree this generally requires that the taxpayer presently have some administrative, financial or managerial position prior to or at the time engaging in the educational activity. In the tax court case of Allemeir v. Comm'r (TC memo 2005-207) the court liberally construed the requirements of the regulation for deductibility. In that case taxpayer had been employed as a salesman for a company making removable orthodontic devices. He had a Bachelor's degree in sports medicine and performed very well in his position so that his responsibilities increased over the years. In addition to sales duties his additional responsibilities included designing marketing strategies, organizing seminars and promoting various products. All of this occurred prior to his obtaining an MBA degree. Taxpayer completed his degree in 2001 and during the two years he was attending the university he received several promotions causing his duties to expand even further to include such functions as analyzing financial statements. The principal issue here was whether the MBA degree qualified the taxpayer for a new trade or business. The IRS argued that his duties which had increased over the years after he enrolled in the MBA program indicated that he had stepped into a new trade or business. The court did not agree and stated its position that the MBA degree enhanced taxpayer's skills which were already being used in his position and did not qualify him for a new trade or business. Taxpayer continued to perform the same tasks after receiving his degree as he had done prior, involving marketing, finance and management duties. The court also distinguished an MBA degree from educational programs qualifying taxpayer for professional certification or licensing such as law school expenses.

Where the education expenses are deductible the deduction includes amounts spent for tuition, books, supplies (Treas. Reg. 1.162-5(c)), and reasonable expenses for research and typing (Rev. Rul. 67-421, 1967-2 CB 84). Local transportation expenses incurred in connection with the education may be included as deductible expenses. These expenses include bus, subway, taxi or other fares as well as the cost of using taxpayers own car (IRS Pub. No. 970 (2009).

Travel expenses, meals and lodging incurred while away from home may also be deductible if they are undertaken primarily to attend tax deductible educational functions (Treas. Reg. 1.162-5(e)(1)). An allocation between deductible and nondeductible expenses would have to be made if any of these expenses are attributable to personal activities such as sightseeing or social events in addition to the education activities. With respect to this allocation, if the primary purpose of the trip was educational, such as to attend a three-day seminar, then the entire cost of travel would be deductible even though taxpayer spent minimal time on personal activities during the trip. Only meals and lodging relating to the educational portion of the trip would be deductible. If however the primary purpose of the trip was for personal purposes and taxpayer happened to have attended an educational event such as a seminar while away on this personal trip then the travel cost would not be deductible but any direct costs of the education including meals and local transportation incurred in connection therewith would be deductible. In either case the local transportation expenses, the meals and lodging are deductible only if they can be attributed to the time spent on educational activities (Reg. 1.162-5(e)(1)). 
In a frequently cited tax court case, taxpayer was an English teacher who traveled to Greece and Southeast Asia for university extension courses which she took primarily to enhance her skills in her teaching position. Needless to say there were significant elements of personal activities during the trip. However, taxpayer spent at least five hours a day on course work during seventeen of the eighteen days of the trip. Despite taxpayer's ancillary personal activities all of her travel expenses were deductible except for minimal personal costs (Jorgensen, 2000, TC Memo 2000-138).

IRC Section 274(h)(1) address the issue of seminar cruises and similar trips as education expenses. This section will not allow any education expense deduction for these expenses which are incurred outside of North America unless the taxpayer establishes that the meeting is directly related to the active conduct of taxpayer's trade or business, as has been illustrated thus far. Further, it must be as reasonable for the meeting to be held outside of North America as within North America. Some of the factors to be considered in connection with this determination are the purpose of the meeting and the activities taking place at the meeting, the residences of the members of the sponsoring organization and the locations at which other meetings of the organization have been held. This is a heavy burden for educational activities which could as well have been held in North America as outside North America. In Reuben, (1961) 35 TC 566, a Mediterranean cruise was the site of a medical seminar. In its decision the Court noted that the seminar was given over an eighteen day cruise by five professors with affiliations with Duke University School of Medicine. The cruise however was arranged by a travel agency, Duke University was not officially a party to the seminar and received no fees or compensation for this cruise and the certificate of completion for the seminar was signed by the individual lecturers. Instead the lecturers received free passage on the cruise. The Court further noted that the brochure advertising the cruise consisted of eight pages, only one of which was devoted to the proposed medical program with the balance containing attractive pictures of the area to be visited and other attractive vacation sites. The Court concluded that the taxpayer participated in the cruise primarily because of pleasure considerations and only secondarily for educational purposes and thus allowed only $12 \%$ of the cost of the cruise as a deductible educational expense because only $12 \%$ of the trip was allocable to lectures and coursework. In similar cases the Tax Court denied an English teacher a deduction for traveling to places in Europe which she claimed gave her new insights into the material she taught for the benefit of her students (Garcia, TC Summary Opinion 2005-2) and the IRS did not allow the claimed deduction by a speech and drama teacher for expenses on sabbatical leave for travel to various countries to visit theater productions in various localities in order to study various teaching methods (IRS letter Ruling 8950016). A deduction was allowed however for a teacher's travel expenses for extension courses in Greece and Southeast Asia where the courses had clear educational purposes beyond mere travel. The courses were given by University professors and included tours of related sites and significant reading assignments so that the education consisted of activities other than travel itself although it included significant amounts of travel (Jorgensen (TC Memo 2000-138)).

IRC Section 274(m)(2) denies a deduction for the expenses of travel as a form of education even though the travel may be directly related to the taxpayer's duties. This rule prevents a deduction which is sought when the travel itself is to serve as educational rather than traveling to a place for an educational event. For example, IRS Publication 970 (2009) contains the example of a language teacher who travels through France while on sabbatical to improve her knowledge of the French language and French culture. Her itinerary is carefully selected to attend activities which will improve her language skills and although she spends most of the time visiting French schools and families and attending cultural events these travel expenses are not deductible as educational expenses.

The costs of research, including travel, have been the subject of IRS determinations. College professors engage in lecture and teaching as their principal duties. However, related duties also involve the communication and advancement of knowledge through research and publication. Appointments and promotions are commonly made with the expectation that the professor will engage in independent research, seek advances in their fields and generate publications, all of which contribute to the body of learning. These functions are indeed expected in carrying out the duties of a professor. In this regard, the position of the IRS is that while they will allow the costs related to these activities as deductions, " ( $\mathrm{t}$ )he responsibility rests with each professor to show that the amounts claimed are reasonable in relation to the research performed and that the research is in his area of competence; that is, that the research is directly related to the general field in which the professor is performing services as an educator". Rev. Rul. 63-275; $1963-2$, CB 85. 


\section{AUTHOR INFORMATION}

William A. Bottiglieri, MBA, CPA, JD, is an Associate Professor in Accounting at Iona College, New Rochelle, New York and is in private practice as a tax accountant. E-mail: wbottiglieri@iona.edu

Steven L. Kroleski, JD is an Associate Professor in Business Law at Iona College, New Rochelle and is in private practice as an attorney. E-mail: skroleski@iona.edu

\section{REFERENCES}

1. Allemeir v. Comm'r (TC memo 2005-207)

2. Blackmer v. Commr., 13AFTR957

3. Galligon (TC Memo 2002-150)

4. Garcia, TC Summary Opinion 2005-2

5. Internal Revenue Code of 1986, as amended (IRC), Sec. 162

6. $\quad$ IRS letter Ruling 8950016

7. IRS letter Ruling 9316005

8. IRS Pub. No. 970 (2009)

9. Jorgensen (TC Memo 2000-138)

10. Jorgensen, 2000, TC Memo 2000-138

11. McEwen (TC Memo 2004-107)

12. Reuben, (1961) 35 TC 566

13. Rev. Rul. 63-275; $1963-2$, CB 85

14. Rev. Rul. 67-421, 1967-2 CB 84

15. Rev. Rul. 75-120, 1975-1 CB 55

16. Rev. Rule 60-97, 1960-1 CB 69

17. Treas. Reg. 1.162-5(a)

18. Treas. Reg. 1.162-5(b)

19. Treas. Reg. 1.162-5(b)(3)(i)

20. Treas. Reg. 1.162-5(b)(3)(ii)

21. Treas. Reg. 1.162-5(c)

22. Treas. Reg. 1.162-5(e)(1)

23. Treasury Regulation 1.162-5

24. Welch v. Helvering, 12AFTR1456 


\section{NOTES}

